\title{
Research Paper Credit utilization pattern of Kisan Credit Card in South Gujarat
}

\author{
Y. L. Meghana, J. J. Makadia and N. A. Kalola
}

See end of the paper for authors' affiliations

Correspondence to :

\section{J.J. Makadia}

Department of Agricultural Economics, N. M. College of Agriculture, Navsari Agricultural University, Navsari (Gujarat) India Email:jjmakadia@yahoo. com

\section{Paper History :}

Received : 24.11.2017;

Revised : 05.01.2018;

Accepted : 19.01 .2018
ABSTRACT : The study was undertaken to determine credit utilization pattern of Kisan Credit Cards in South Gujarat during 2016-17. The study was based on the information obtained from 80 KCC holders and 80 Non-KCC holders selected from two districts Navsari and Surat of South Gujarat. The results revealed that the majority of KCC holders fully utilized the credit $(46.25 \%)$ followed by not utilized(17.50\%) and fully mis-utilized (17.50\%) for the productive purpose. About 85.13 per cent amount of total loan disbursed was properly utilized by sample KCC holders. Major reason misutilization of credit by KCC holder was found to salting of old debts and other reasons $(33.33 \%)$. Major constraints in availing and use of KCC as perceived by farmer lengthy paper work followed by insufficient credit limit, high interest rate etc.

KEY Words : Kisan Credit Card, Holders, Utilization

How To Cite This PAper : Meghana, Y.L., Makadia, J.J. and Kalola, N.A. (2018). Credit utilization pattern of Kisan Credit Card in South Gujarat. Internat. Res. J. Agric. Eco. \& Stat., 9 (1) : 31-34, DOI : 10.15740/HAS/ IRJAES/9.1/31-34. 